\title{
Flavonoids of the Heartwood of Cotinus coggygria Scop. Showing Protective Effect on Human Lymphocyte DNA
}

Natural Product Communication

Volume 16(12): 1-8

(C) The Author(s) 2021

Article reuse guidelines: sagepub.com/journals-permissions

DOI: $10.1177 / 1934578 X 211067289$ journals.sagepub.com/home/npx

\author{
Slobodan Milosavljevic ${ }^{1}$, Iris Djordjevic ${ }^{2}$, Boris Mandic ${ }^{3}$, Vele Tesevic ${ }^{3}$, \\ Miroslava Stankovic ${ }^{4}$, Nina Todorovic ${ }^{5}$, and Miroslav Novakovic ${ }^{5, *}$ (D)
}

\begin{abstract}
In continuation of our study on Cotinus coggygria from Serbia, 10 known flavonoids (1-10) were isolated from the methylene chloride/ methanol extract of the heartwood. They were tested for in vitro protective effect against chromosome aberrations in peripheral human lymphocytes, using the cytokinesis-block micronucleus assay. All tested compounds (in minimal doses of $1 \mu \mathrm{g} / \mathrm{mL}$ ) exerted a beneficial effect by decreasing DNA damage of human lymphocytes in the range of $24.2 \%$ to $54.5 \%$, better than the radio protectant control, amifostine. Functional groups, such as $3^{\prime}, 4^{\prime}$-dihydroxyphenyl (catechol), 5-OH, 3-OH, and 4-keto in flavonoids (3-keto in aurones), which play a key role in antioxidant activity, are proposed to be responsible for the DNA protective activity of the tested compounds.
\end{abstract}

\section{Keywords}

flavonoids, Cotinus coggygria Scop., DNA protective activity, cytokinesis-block micronucleus assay

Received: October 8th, 2021; Accepted: November 26th, 2021.

\section{Introduction}

The genus Cotinus (family Anacardiaceae) comprises 8 species, namely Cotinus coggygria Scop. (syn. Rhus cotinus L.), Cotinus obovatus Raf., Cotinus americana Nutt., Cotinus carranzae Rzed. and Calderon, Cotinus chiangii (D. A. Young) Rzed. and Calderón, Cotinus kanaka (R. N. De) D. Chandra, Cotinus nanus W. W. Sm., and Cotinus szechuanensis Pénzes. ${ }^{1}$ C. coggygria, a shrubby tree, also known as the European smoketree, is native to a large area from southern Europe to northern China, inhabiting mainly dry slopes, rocky and gravely areas in forest clearings, and south-facing limestone soils. In Serbia, C. coggygria is widely distributed, especially on limestone and sedimentary rocks and in the forests of black hornbeam and black pine. In folk medicine of various countries, as well as in Serbia, this plant is used for the treatment of different health problems. Extracts of the various parts (leaves, flowers, heartwood, and bark) and essential oils obtained from leaves of $C$. coggygria showed a broad spectrum of pharmacological activities, including antioxidant, anticancer, antigenotoxic, antimicrobial, antiviral, hepatoprotective, and antiinflammatory. ${ }^{2}$ Flavonoids are the most important and abundant group of biologically active constituents of Cotinus species, followed by phenolic acids, sterols, and other secondary metabolites. Previously reported compounds isolated from the wood of
$C$ coggygria are sulfuretin, fustin, 3-O-methyl-2,3-trans-fustin, 3-O-galloyl-2,3-trans-fustin, fisetin, garbanzol, eriodyctiol, butein, butin, taxifolin, quercetin, catechin, liquiritigenin, isoliquiritigenin, disulfuretin, sulfurein, gallic acid, methyl gallate, pentagalloyl glucose, $\beta$-resorcylic acid, gallic acid, gallic acid methyl ester, 3 - $O-\beta$-sitosterol glucoside, fisetinidol- $(4 \alpha \rightarrow 8)-(+)$-catechin, and epifisetinidol- $(4 \beta \rightarrow 8)-(+)$-catechin, a dimer of butin. ${ }^{5}$ In continuation of our examination of $C$. coggygria from Serbia ${ }^{4,9}$ and searching for compounds with a possible antigenotoxic activity, ${ }^{10}$ we now report the evaluation of the DNA protective

\footnotetext{
${ }^{1}$ Serbian Academy of Sciences and Arts, Belgrade, Serbia

${ }^{2}$ Faculty of Veterinary Medicine, University of Belgrade, Belgrade, Serbia

${ }^{3}$ Faculty of Chemistry, University of Belgrade, Belgrade, Serbia.

${ }^{4}$ Vinca Institute of Nuclear Sciences, Vinca, Serbia

${ }^{5}$ Instituite of Chemistry, Technology and Metallurgy, Department of Chemistry, University of Belgrade, Belgrade, Serbia

*Dedicated to Professor Yoshinori Asakawa on the occasion of his 80th birthday.

Corresponding Author:

Miroslav Novakovic, Institute of Chemistry, Technology and Metallurgy, Department of Chemistry, University of Belgrade, Njegoseva 12, 11000 Belgrade, Serbia.

Email: mironov@chem.bg.ac.rs; mironov76@yahoo.com
} 
activity of the flavonoids 1-10, isolated from the heartwood of C. coggygria, based on their ability to reduce the formation of micronuclei (MN) in the cytokinesis-block micronucleus (CBMN) assay.

The CBMN assay used in this study is a technique that is widely recognized as one of the most reliable and successful assays for genotoxic studies. The recording of the frequency of $\mathrm{MN}$, commonly used as a cytogenetic biomarker (and MN expression in peripheral blood lymphocytes) is well established as a method for monitoring chromosome damage in human populations. The method originally proposed by Countryman and Heddle ${ }^{14}$ was subsequently improved with the development of CBMN assay, which has been extensively used to evaluate chromosome damage in human populations. ${ }^{15}$ This technique, a couple of years ago endorsed by the Organisation for Economic Co-operation and Development, is considered one of the most robust methods for assessing cytotoxicity and genotoxicity. ${ }^{18}$ The application of CBMN assay for antioxidant evaluation of heterocyclic compounds, including flavonoids (until 2011), is reviewed elsewhere. ${ }^{13}$

An important effect of flavonoids is the scavenging of oxygenderived free radicals. This has been the subject of several studies in the past few years, and important structure-activity relationships of the antioxidant activity have been established. ${ }^{19}$ Antioxidants protect against molecular damage in living organisms from reactive oxygen species (ROS), such as DNA damage altering gene expression, cell growth, and differentiation. ${ }^{20,21}$ As oxidative DNA damage is considered to be a pathogenic event in the induction of many illnesses (eg, Alzheimer's and Parkinson's diseases, cancer, and diabetes), ${ }^{22}$ decreasing the degree of such damage by plant polyphenols may reduce the risks.

\section{Results and Discussion}

Compounds 1-10 (comprising 4 flavonoid subclasses), that is, chalcone butein (1), aurone sulfuretin (2), auronolignan cotinignan A (3), and 7 flavanones, eriodictyol (4), taxifolin (5), butin (6), fustin (7), cis-methylfustin (8), fustin-3-O-gallate (9), and garbanzol (10) (Figures 1 and 2) were isolated from the heartwood of $C$. coggygria using silica gel column chromatography (CC) followed by preparative thin-layer chromatography (TLC) and semipreparative reversed-phase high-performance liquid chromatography (HPLC). These compounds, except garbanzol, have already been isolated from Serbian C. coggygria in our previous work and the most abundant compounds by far were fustin and sulfuretin, isolated in amounts over $100 \mathrm{mg}$, while other compounds were isolated in the range of 2 to 10 mg (see the "Experimental" section). ' Considering that oxidative stress causes DNA damage with the formation of $\mathrm{MN}$, and with 10 isolated flavonoids-well-known antioxidants, ${ }^{19}$ our idea was to examine these compounds by CBMN assay and determine their possible protective effect against chromosome aberrations in peripheral human lymphocytes.

The majority of the studied compounds, occurring in many plant species, belong to the group of pharmacologically active metabolites with a wide spectrum of biological activities such as anticancer, antioxidant, antiinflammatory, and antiviral. ${ }^{25}$ All tested flavonoids, except $\mathbf{3}$ and $\mathbf{1 0}$, contain a $3^{\prime}, 4^{\prime}$-dihydroxyphenyl group (catechol structure) as the B ring (Figure 1), possessing electron-donating properties and being a radical target, which is beneficial for the antioxidant activity of flavonoids. ${ }^{19}$

The CBMN assay of $\mathbf{1 - 1 0}$ was carried out according to the standard procedure applied previously in our laboratory, ${ }^{10}$ using the radio protectant amifostine WR-272 $(1.0 \mu \mathrm{g} / \mathrm{mL})$ as a positive control, and the alkylating agent mitomycin $\mathrm{C}$ (MMC) $(0.2 \mathrm{mg} / \mathrm{mL})$ as a negative control. ${ }^{39}$ The results of the CBMN assay are summarized in Table 1 and Figure 2. The treatment with alkylating agent $\mathrm{MMC}$ at a concentration of $0.2 \mu \mathrm{g} / \mathrm{mL}$ gave a significant $(P<.01)$ increase in the $\mathrm{MN}$ frequency of $32.6 \%$ compared to the control cell cultures. The cell cultures treated with amifostine WR-2721 at a concentration of $1.0 \mu \mathrm{g} / \mathrm{mL}$ effected a significant $(P<.01)$ decrease in the MN frequency of $18.3 \%$ compared to the control cell cultures (Table 1). The highest activity for all compounds was obtained at a concentration of $4.0 \mu \mathrm{g} / \mathrm{mL}$.

All the tested compounds (in minimal doses of $1.0 \mu \mathrm{g} / \mathrm{mL}$ ) decreased the DNA damage of human lymphocytes in the range of $24.2 \%$ to $54.5 \%$, more effectively than amifostine at the same concentration. Among the tested compounds, eriodictyol (4) exhibited the most prominent effect decreasing significantly $(P<.01)$ the frequency of $\mathrm{MN}$ by $54.5 \%$ when compared with the control cell cultures. Compound 4 is abundantly present in a wide range of medicinal plants, citrus fruits, and vegetables that are considered to have potential health importance. Several studies have indicated that eriodictyol exerts multiple therapeutic effects including antioxidant, antiinflammatory, anticancer, neuroprotective, cardioprotective, antidiabetic, antiobesity, hepatoprotective, and others. ${ }^{25}$ The same concentration $(1.0 \mu \mathrm{g} / \mathrm{mL})$ of the related co-occurring 5-hydroxy flavanone, possessing a 3-OH substituent, taxifolin (5) also caused a significant $(P<.01)$ decrease in the MN frequency by $47.6 \%$. As reported previously, taxifolin was found to act as a powerful antioxidant, antiradical, and metal-chelating agent in different in vitro bioassays. ${ }^{26}$ The smaller effect of $\mathbf{5}$, in comparison with that of 4 , could be in accordance with the relative order of their antioxidant efficacy, that is, $\mathbf{4}>\mathbf{5}$, reported elsewhere. ${ }^{27}$ Taxifolin is a flavonoid commonly found in onion, milk thistle, French maritime (Pinus pinaster) pine bark, and Douglas fir (Pseudotsuga menziesii) bark. Taxifolin showed promising pharmacological activities in the management of inflammation, tumors, microbial infections, oxidative stress, cardiovascular, and liver disorders. The anticancer activity was more prominent than other activities evaluated using different in vitro and in vivo models. ${ }^{28}$ The remaining $3^{\prime}, 4^{\prime}$-dihydroxy group of flavanones lacking a 5-OH substituent (6-9) exhibited a less protective effect $(25.6-41.4 \%)$ than 4 and $\mathbf{5}$ at the same concentration $(1.0 \mu \mathrm{g} / \mathrm{mL})$. The flavanone, butin (6), with the highest activity in this group (41.4\%), is one of the most widely distributed flavonoids. As previously reported, this compound showed pronounced antioxidant activity. ${ }^{29}$ The protective effect of $\mathbf{6}$ 


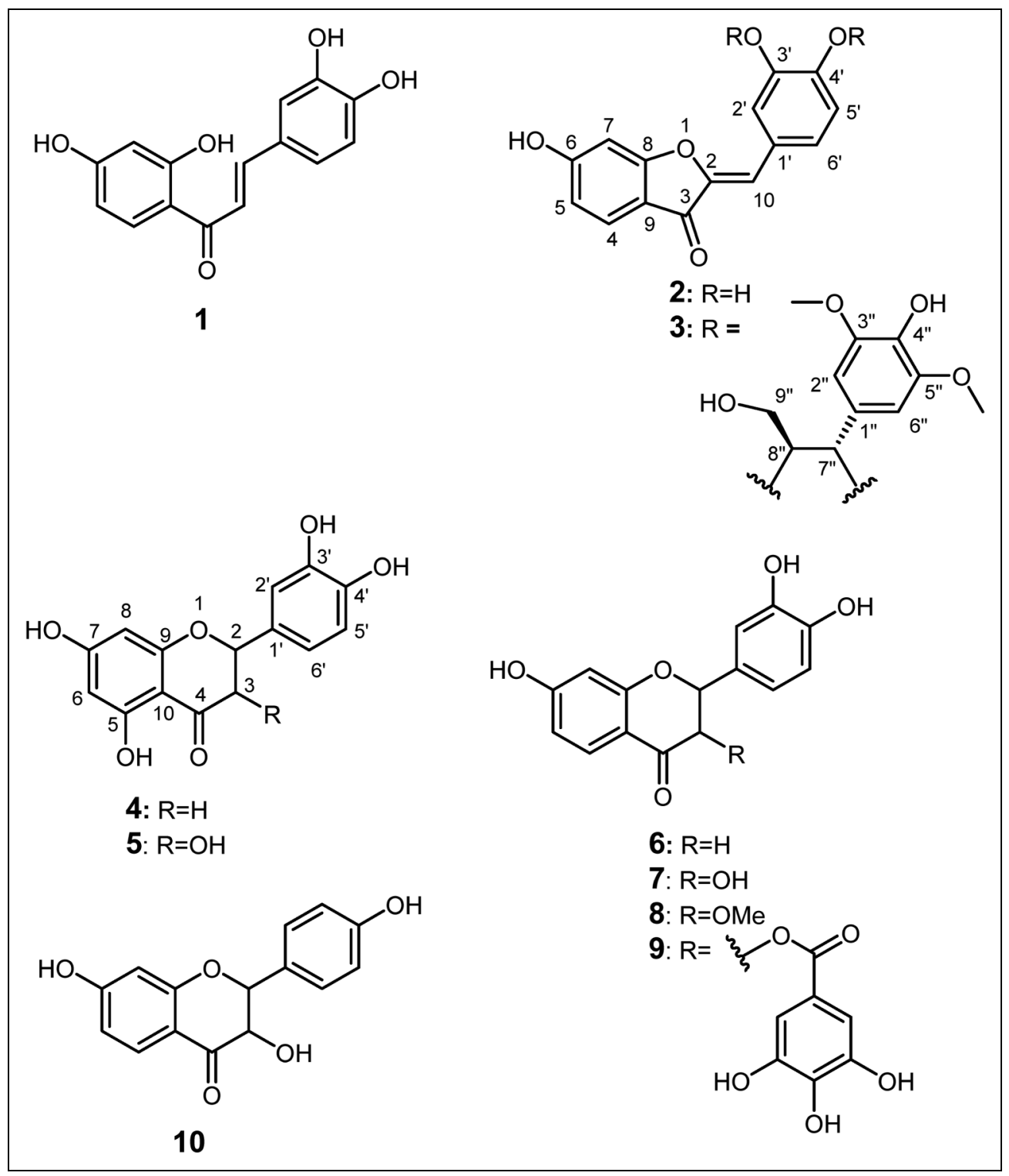

Figure 1. Flavonoids from Cotinus coggygria that were tested for DNA protective activity.

against hydrogen peroxide-induced apoptosis by scavenging ROS and activating antioxidant enzymes has also been reported previously. ${ }^{30}$ A rather potent antioxidant, fustin (7), ${ }^{31}$ having the ability to act against disorders caused by oxidative stress, ${ }^{32}$ exhibited a lower $(30.2 \%)$, but still substantial activity in comparison with that of $\mathbf{5}$. Methylation of the 3-OH group, comparing compounds $\mathbf{7}$ and $\mathbf{8}$, slightly enhanced the activity of $8(34.9 \%)$. It is interesting to note that the protective activity $(25.6 \%)$ of the 3-O-galloyl-derivative of fustin (9) was lower than that of fustin $(30.2 \%)$, despite the fact that gallic acid itself, as well as the related 3-O-galloyl flavonoid derivatives, lacking a carbonyl function at $\mathrm{C}-4$, such as gallocatechins, are among the strongest antioxidants. ${ }^{39}$ As expected, the lowest activity $(24.2 \%)$ was observed for garbanzol $(\mathbf{1 0})$, the only flavanone among the tested compounds lacking a $3^{\prime}, 4^{\prime}$ - dihydroxyphenyl group in the B ring, which is the key structural feature known to be responsible for the radical scavenging, antioxidant, antiinflammatory, and antiprotein aggregation activities. ${ }^{40}$

Butein (1) and sulfuretin (2), belonging to the flavonoid subclasses with emerging therapeutic potential, that is, chalcones and aurones, respectively, also exhibited significant DNA protective activities at a concentration of $1.0 \mu \mathrm{g} / \mathrm{mL}(35.3 \%$ and $40.5 \%$, respectively), which is due to their radical scavenging ability. $^{35,41}$ Hitherto, butein (1) has been found in different parts of several plant species belonging to diverse families: for example, Anacardiaceae, Asteraceae, and Fabaceae. ${ }^{36}$ This compound is one of the major biologically active components of the bark and stems of Rhus verniciflua Stokes. ${ }^{42}$ In far eastern countries, such as Korea, Japan, and China, butein (1) has been 


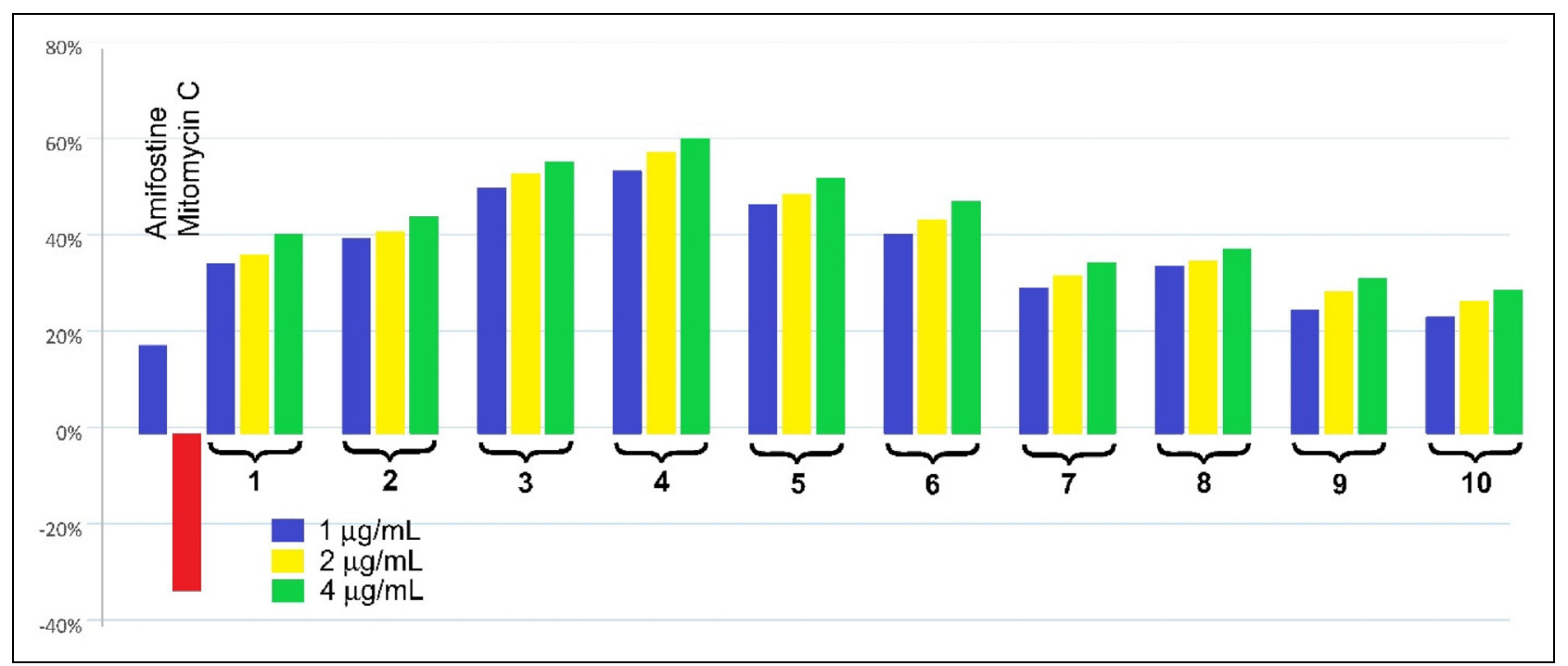

Figure 2. Decrease in frequency of MN (\%) in comparison with the control (100\%) (see Table 1) effected by flavonoids 1-10; amifostine (positive control) and mitomycin C (negative control).

traditionally used for the treatment of pain, thrombotic disease, gastritis, stomach cancer, and parasitic infections. ${ }^{42}$ In Korea, it has also long been used as a food additive. ${ }^{43}$ Its significant chemotherapeutic potential has been reviewed elsewhere. ${ }^{35,41,44}$ The antioxidant activities of $\mathbf{1}$ are primarily attributed to its free radical scavenging actions and metal ion chelation. ${ }^{44}$

Sulfuretin (2), one of the major biologically active constituents of the heartwood of $R$. verniciflua ${ }^{33}$ and $C$. coggygria is known to have various biological activities, including antiinflammatory, antimutagenic, anticancer, antioxidative stress, antiplatelet, and antiarthritis effects. In a previously reported activity-guided isolation of constituents of C. coggygria ${ }^{6}$, as well as in the identification of $R$. verniciflua compounds exhibiting free radical scavenging and antiapoptotic properties, sulfuretin was identified as one of the significant antioxidative component. $^{45}$

Cotinignan A (3), recently isolated from C. coggygria ${ }^{9}$ and representing a new subclass of secondary metabolites-auronolignans, exhibited a protective activity of $50.9 \%$ (at the concentration of $1.0 \mu \mathrm{g} / \mathrm{mL}$ ), higher than that of sulfuretin (Figure 2 and Table 1). Such a result could possibly be explained by the presence of a free $4^{\prime \prime}$-OH group, which is important for the radical scavenging activity of flavonolignans, as well as the enhanced lipophilicity caused by blocking of reactive $3^{\prime}, 4^{\prime}, 3^{\prime \prime}, 5^{\prime \prime}-\mathrm{OH}$ groups. ${ }^{46}$

\section{Conclusion}

In this study, the DNA protective activity is presented of 10 known flavonoid compounds from C. coggygria. All of the investigated compounds exhibited better activity than the radio protectant amifostine, while eriodyctiol was the best protector, decreasing the MN frequency by $54.5 \%$. Functional groups responsible for the antioxidant activity of flavonoids, 3',4'-dihydroxyphenyl (catechol), 5-OH, 3-OH, and 4-keto (3-keto in aurones) are supposed to influence DNA protective activity in CBMN assay as well. Further investigation, including DNA protective activity against irradiation damage, will give a wider picture of the protective activity of $C$. coggygria flavonoids.

\section{Experimental}

\section{General Experimental Procedures}

For CC, Merck silica gel (Si gel) (particle size 0.063-0.200 mm), methanol, methylene chloride, and chloroform were used. Preparative TLC (Prep TLC) was performed on glass plates precoated with silica gel 60 (particle size $<0.063 \mathrm{~mm}$ ) with a layer thickness of $0.75 \mathrm{~mm}$. Analytical TLC was performed on aluminum plates precoated with Merck silica gel $60 \mathrm{~F}_{254}$ (0.25 mm thickness). The nuclear magnetic resonance (NMR) spectra were obtained on a Bruker Avance III $500(500 \mathrm{MHz}$ for ${ }^{1} \mathrm{H}$; $125 \mathrm{MHz}$ for ${ }^{13} \mathrm{C}$ ), in $\mathrm{CD}_{3} \mathrm{OD}$ as a solvent. Chemical shifts $(\boldsymbol{\delta})$ were expressed in ppm and coupling constants $(J)$ in hertz $(\mathrm{Hz})$. Semipreparative reversed phased HPLC was performed on an Agilent Technologies 1100 Series HPLC-DAD, and a Zorbax Eclipse XDB C18 column $(150 \times 9.4 \mathrm{~mm}, 5$ $\mu \mathrm{m})$ was used.

\section{Plant Material, Extraction, Isolation, and Identification of Compounds}

The C. coggygria heartwood was collected at Deliblatska Peščara (Deliblato Sand), Vojvodina province, Serbia, in June 2018. Plant material was identified by Professor Milan Veljić, Faculty of Biology, University of Belgrade, and voucher specimen BEOU 17422 was deposited at the Herbarium of the 
Table 1. Incidence of MN, Cytokinesis-Block Proliferation index, Distribution of MN per Cells, and Frequency of MN Measured in Cell Cultures of Human Lymphocytes Treated with Different Concentrations of the Isolated Compounds From Cotinus coggygria.

\begin{tabular}{|c|c|c|c|c|c|c|}
\hline Compound & conc. $(\mu \mathrm{g} / \mathrm{mL})$ & $\mathrm{MN} / 1000 \mathrm{BN}$ cells & $\% \mathrm{BN}$ cells with $\mathrm{MN}$ & $\mathrm{MN} / \mathrm{BN}$ cells & CBPI & Frequency of MN \\
\hline Control & & $27.83 \pm 0.40$ & $2.36 \pm 0.06$ & $1.19 \pm 0.03$ & $1.68 \pm 0.05$ & $100 \%$ \\
\hline Amifostine & 1.0 & $22.74 \pm 0.51^{\mathrm{a}}$ & $1.88 \pm 0.04$ & $1.21 \pm 0.03$ & $1.64 \pm 0.02$ & $81.7 \%$ \\
\hline MMC & 0.2 & $36.90 \pm 0.85^{\mathrm{a}, \mathrm{b}}$ & $3.37 \pm 0.13$ & $1.09 \pm 0.03$ & $1.68 \pm 0.08$ & $132.6 \%$ \\
\hline \multirow[t]{3}{*}{1} & 1.0 & $18.00 \pm 0.61^{\mathrm{a}, \mathrm{b}, \mathrm{c}}$ & $1.53 \pm 0.07$ & $1.18 \pm 0.03$ & $1.71 \pm 0.08$ & $64.7 \%$ \\
\hline & 2.0 & $17.50 \pm 0.38^{\mathrm{a}, \mathrm{b}, \mathrm{c}}$ & $1.47 \pm 0.07$ & $1.19 \pm 0.05$ & $1.63 \pm 0.01$ & $62.9 \%$ \\
\hline & 4.0 & $16.31 \pm 0.60^{\mathrm{a}, \mathrm{b}, \mathrm{c}}$ & $1.39 \pm 0.03$ & $1.17 \pm 0.05$ & $1.60 \pm 0.02$ & $58.6 \%$ \\
\hline \multirow[t]{3}{*}{2} & 1.0 & $16.57 \pm 0.84^{\mathrm{a}, \mathrm{b}, \mathrm{c}}$ & $1.51 \pm 0.10$ & $1.10 \pm 0.04$ & $1.62 \pm 0.04$ & $59.5 \%$ \\
\hline & 2.0 & $16.18 \pm 0.56^{\mathrm{a}, \mathrm{b}, \mathrm{c}}$ & $1.51 \pm 0.09$ & $1.08 \pm 0.03$ & $1.58 \pm 0.03$ & $58.1 \%$ \\
\hline & 4.0 & $15.32 \pm 1.14^{\mathrm{a}, \mathrm{b}, \mathrm{c}}$ & $1.32 \pm 0.07$ & $1.15 \pm 0.04$ & $1.70 \pm 0.11$ & $55.0 \%$ \\
\hline \multirow[t]{3}{*}{3} & 1.0 & $13.66 \pm 0.30^{\mathrm{a}, \mathrm{b}, \mathrm{c}}$ & $1.18 \pm 0.05$ & $1.17 \pm 0.04$ & $1.65 \pm 0.04$ & $49.1 \%$ \\
\hline & 2.0 & $12.81 \pm 1.26^{\mathrm{a}, \mathrm{b}, \mathrm{c}}$ & $1.05 \pm 0.09$ & $1.21 \pm 0.05$ & $1.62 \pm 0.02$ & $46.0 \%$ \\
\hline & 4.0 & $12.13 \pm 1.51^{\mathrm{a}, \mathrm{b}, \mathrm{c}}$ & $1.09 \pm 0.11$ & $1.10 \pm 0.04$ & $1.53 \pm 0.01$ & $43.6 \%$ \\
\hline \multirow[t]{3}{*}{4} & 1.0 & $12.67 \pm 0.44^{\mathrm{a}, \mathrm{b}, \mathrm{c}}$ & $1.07 \pm 0.11$ & $1.21 \pm 0.10$ & $1.66 \pm 0.08$ & $45.5 \%$ \\
\hline & 2.0 & $11.59 \pm 0.47^{\mathrm{a}, \mathrm{b}, \mathrm{c}}$ & $0.95 \pm 0.06$ & $1.19 \pm 0.01$ & $1.66 \pm 0.08$ & $41.6 \%$ \\
\hline & 4.0 & $10.76 \pm 0.42^{\mathrm{a}, \mathrm{b}, \mathrm{c}}$ & $0.86 \pm 0.05$ & $1.22 \pm 0.06$ & $1.70 \pm 0.07$ & $38.7 \%$ \\
\hline \multirow[t]{3}{*}{5} & 1.0 & $14.58 \pm 0.83^{\mathrm{a}, \mathrm{b}, \mathrm{c}}$ & $1.32 \pm 0.08$ & $1.10 \pm 0.02$ & $1.70 \pm 0.08$ & $52.4 \%$ \\
\hline & 2.0 & $14.00 \pm 1.28^{\mathrm{a}, \mathrm{b}, \mathrm{c}}$ & $1.28 \pm 1.06$ & $1.12 \pm 0.07$ & $1.61 \pm 0.03$ & $50.3 \%$ \\
\hline & 4.0 & $13.07 \pm 0.47^{\mathrm{a}, \mathrm{b}, \mathrm{c}}$ & $1.09 \pm 0.01$ & $1.21 \pm 0.05$ & $1.61 \pm 0.03$ & $47.0 \%$ \\
\hline \multirow[t]{3}{*}{6} & 1.0 & $16.31 \pm 0.80^{\mathrm{a}, \mathrm{b}, \mathrm{c}}$ & $1.44 \pm 0.08$ & $1.13 \pm 0.03$ & $1.67 \pm 0.03$ & $58.6 \%$ \\
\hline & 2.0 & $15.49 \pm 0.94^{\mathrm{a}, \mathrm{b}, \mathrm{c}}$ & $1.32 \pm 0.04$ & $1.16 \pm 0.07$ & $1.66 \pm 0.03$ & $55.6 \%$ \\
\hline & 4.0 & $14.43 \pm 0.81^{\mathrm{a}, \mathrm{b}, \mathrm{c}}$ & $1.22 \pm 0.10$ & $1.18 \pm 0.06$ & $1.63 \pm 0.04$ & $51.8 \%$ \\
\hline \multirow[t]{3}{*}{7} & 1.0 & $19.43 \pm 0.76^{\mathrm{a}, \mathrm{b}, \mathrm{c}}$ & $1.67 \pm 0.14$ & $1.18 \pm 0.11$ & $1.64 \pm 0.01$ & $69.8 \%$ \\
\hline & 2.0 & $18.70 \pm 0.53^{\mathrm{a}, \mathrm{b}, \mathrm{c}}$ & $1.60 \pm 0.08$ & $1.12 \pm 0.05$ & $1.72 \pm 0.08$ & $67.2 \%$ \\
\hline & 4.0 & $17.93 \pm 0.70^{\mathrm{a}, \mathrm{b}, \mathrm{c}}$ & $1.57 \pm 0.07$ & $1.14 \pm 0.04$ & $1.77 \pm 0.08$ & $64.5 \%$ \\
\hline \multirow[t]{3}{*}{8} & 1.0 & $18.11 \pm 0.50^{\mathrm{a}, \mathrm{b}, \mathrm{c}}$ & $1.61 \pm 0.12$ & $1.13 \pm 0.08$ & $1.61 \pm 0.02$ & $65.1 \%$ \\
\hline & 2.0 & $17.88 \pm 0.41^{\mathrm{a}, \mathrm{b}, \mathrm{c}}$ & $1.47 \pm 0.08$ & $1.21 \pm 0.05$ & $1.66 \pm 0.03$ & $64.2 \%$ \\
\hline & 4.0 & $17.18 \pm 0.55^{\mathrm{a}, \mathrm{b}, \mathrm{c}}$ & $1.37 \pm 0.03$ & $1.24 \pm 0.06$ & $1.61 \pm 0.02$ & $61.7 \%$ \\
\hline \multirow[t]{3}{*}{9} & 1.0 & $20.71 \pm 0.70^{\mathrm{a}, \mathrm{c}}$ & $1.75 \pm 0.10$ & $1.19 \pm 0.08$ & $1.66 \pm 0.06$ & $74.4 \%$ \\
\hline & 2.0 & $19.61 \pm 0.69^{\mathrm{a}, \mathrm{b}^{*}, \mathrm{c}}$ & $1.67 \pm 0.05$ & $1.18 \pm 0.06$ & $1.63 \pm 0.03$ & $70.5 \%$ \\
\hline & 4.0 & $18.87 \pm 0.61^{\mathrm{a}, \mathrm{b}, \mathrm{c}}$ & $1.64 \pm 0.05$ & $1.17 \pm 0.02$ & $1.64 \pm 0.02$ & $67.8 \%$ \\
\hline \multirow[t]{3}{*}{10} & 1.0 & $21.11 \pm 0.62^{\mathrm{a}, \mathrm{c}}$ & $1.75 \pm 0.10$ & $1.16 \pm 0.06$ & $1.66 \pm 0.01$ & $75.8 \%$ \\
\hline & 2.0 & $20.17 \pm 0.43^{\mathrm{a}, \mathrm{b}, \mathrm{c}}$ & $1.65 \pm 0.12$ & $1.24 \pm 0.09$ & $1.67 \pm 0.01$ & $72.5 \%$ \\
\hline & 4.0 & $19.54 \pm 0.70^{\mathrm{a}, \mathrm{b}, \mathrm{c}}$ & $1.64 \pm 0.07$ & $1.20 \pm 0.09$ & $1.62 \pm 0.03$ & $70.2 \%$ \\
\hline
\end{tabular}

$\mathrm{MN} / \mathrm{BN}$ cells=incidence of micronuclei in binucleated cells; $\mathrm{CBPI}=$ cytokinesis-block proliferation index; $\% \mathrm{BN}$ cells with $\mathrm{MN}=\% \mathrm{BN}$ cells with micronuclei; $\mathrm{MN} /$ $1000 \mathrm{BN}$ cells=incidence of micronuclei in 1000 binucleated cells examined for each concentration; Frequency of MN=incidence of MN presented as \% from control groups in cell cultures of human lymphocytes treated with different concentrations of the investigated compounds. The statistical significance of the difference between the data pairs was evaluated by analysis of variance (ANOVA; one-way ANOVA) followed by the Tukey test. Statistical difference was considered significant at $P<.01$.

${ }^{a}$ Compared with control groups, statistically significant difference $P<.01$.

${ }^{\mathrm{b}}$ Compared with amifostine WR-2721, statistically significant difference $P<.01$.

${ }^{\mathrm{b} *}$ Compared with amifostine WR-2721, statistically significant difference $P<.05$.

${ }^{\mathrm{c} C o m p a r e d ~ w i t h ~ m i t o m y c i n ~} \mathrm{C}$, statistically significant difference $P<.01$.

Institute of Botany and Botanical Garden "Jevremovac", Belgrade, Serbia.

The heartwood was air-dried and milled. Wood powder, $100.0 \mathrm{~g}$, was extracted 3 times with $1 \mathrm{~L}$ of $\mathrm{CH}_{2} \mathrm{Cl}_{2} / \mathrm{MeOH}$ $2: 1$ for $24 \mathrm{~h}$ (the first hour of extraction in an ultrasonic bath) at room temperature to give $8.2 \mathrm{~g}$ of crude extract, which was subjected to fractionation by $\mathrm{Si}$ gel CC.

Isolation was performed similarly to our previous work. ${ }^{9}$ Crude extract $(8.2 \mathrm{~g})$ was chromatographed on a Si gel column $(750 \times 45 \mathrm{~mm})$, with $\mathrm{CH}_{2} \mathrm{Cl}_{2} / \mathrm{MeOH}$ (gradient elution, from $95 / 5$ to $60 / 40$ ) and afforded 230 fractions. The eluates were monitored by TLC, and the fractions with similar retention factor values were combined. Pure compounds were isolated from these fractions by additional Si gel CC and/or Prep TLC and semipreparative HPLC. All isolated compounds were identified using ${ }^{1} \mathrm{H}$ and ${ }^{13} \mathrm{C}$ NMR spectroscopy, and comparison to NMR data from our previous work. ${ }^{9}$ Compounds 1 (22 mg), 3 (3 mg), 4 (10 mg), 6 (3 mg), 8 (7 mg), and 10 (2 mg) were isolated from fractions 22 to 53 from the Si gel CC $\left(\mathrm{CH}_{2} \mathrm{Cl}_{2} / \mathrm{MeOH}\right.$ 95:5 ratio), while compounds 2 (>100 mg), $5(8 \mathrm{mg})$, and $7(>100 \mathrm{mg})$ were isolated from fractions 103 to $129\left(\mathrm{CH}_{2} \mathrm{Cl}_{2} / \mathrm{MeOH}\right.$ 88:12 ratio). Compound 9 (2 mg) 
was isolated from the combined fractions 175 to $196\left(\mathrm{CH}_{2} \mathrm{Cl}_{2} /\right.$ $\mathrm{MeOH}$ 75:25 ratio). The semipreparative HPLC program used for the final isolation and purification was the same as in our previous work. ${ }^{9}$

\section{Subjects}

Venous blood samples were obtained by heparinized sterile vacutainers (Becton Dickinson) from 6 healthy nonsmoking male volunteers who had not been exposed to chemicals, drugs, or other substances. A safety protocol concerning bloodborne pathogens/biohazards was adopted. The volunteers gave their permission for using their blood for the experiment. From each subject, 2 aliquots of blood, $5 \mathrm{~mL}$ each were obtained. The study complied with the code of ethics of the World Medical Association (Helsinki Declaration of 1964, as revised in 2002). The blood samples were obtained at the Medical Unit in accordance with current Health and Ethical regulations in Serbia, Law on Health Care (2005).

\section{CBMN Assay}

The culture lymphocytes were treated with compounds 1-10 isolated from $C$ coggygria heartwood at 3 concentrations: 1.0, 2.0, and $4.0 \mu \mathrm{g} / \mathrm{mL}$. One cell culture without added compounds served as the control. One cell culture containing amifostine WR-2721 (Marligen-Biosciences) $(1.0 \mu \mathrm{g} / \mathrm{mL})$ served as the positive control, and another one containing MMC ( $0.2 \mu \mathrm{g} /$ $\mathrm{mL}$, in phosphate buffer) as a negative control. All cultures were incubated in a thermostat at $37^{\circ} \mathrm{C}$. Treatment with compounds lasted for $19 \mathrm{~h}$, after which all cultures were rinsed with pure medium, transferred into $5 \mathrm{~mL}$ fresh Rosewell Park Memorial Institute (RPMI) 1640 medium (RPMI-1640 medium +
GlutaMAX + $25 \mathrm{mM}$ HEPES; Invitrogen-Gibco-BRL), and incubated for an additional $72 \mathrm{~h}$. The incidence of spontaneously occurring $\mathrm{MN}$ in control samples was scored.

About $2 \times 10^{6}$ blood lymphocytes were set up in $5 \mathrm{~mL}$ of RPMI-1640 medium supplemented with $15 \%$ calf serum and $2.4 \mu \mathrm{g} / \mathrm{mL}$ of phytohemagglutinin (Invitrogen-Gibco-BRL). One hour after the start of cell stimulation, the investigated compounds were added to the samples at a final concentration of $1.0,2.0$, or $4.0 \mu \mathrm{g} / \mathrm{mL}$, respectively. The incidence of spontaneously occurring $\mathrm{MN}$ in control samples was scored. For MN preparation, the cytokinesis block method of Fenech was used, with some modifications. ${ }^{14}$ Cytochalasin B (Invitrogen-Gibco-BRL), at a final concentration of $6.0 \mu \mathrm{g} /$ $\mathrm{mL}$, was added to the samples after $44 \mathrm{~h}$, and the lymphocyte cultures were incubated for a further $24 \mathrm{~h}$. After $72 \mathrm{~h}$, the cells were washed with $0.9 \% \mathrm{NaCl}$ (Merck, Sharp, \& Dohme GMBH), collected by centrifugation, and treated with a hypotonic solution at $37{ }^{\circ} \mathrm{C}$. The hypotonic solution consisted of $0.56 \% \mathrm{KCl}+0.9 \% \mathrm{NaCl}$ (mixed in equal volumes). The cell suspension was prefixed in methanol/acetic acid (3:1), washed 3 times with fixative, and dropped onto a clean slide. ${ }^{16}$ Slides were air-dried and stained with alkaline Giemsa (Sigma-Aldrich) (2\%). At least 1000 binucleated (BN) cells per sample were scored, registering $\mathrm{MN}$ according to the criteria of Countryman and Heddle ${ }^{14}$ and Fenech. ${ }^{15,16}$

Initially, we investigated the effects of isolated compounds on cell proliferation by determining the cytokinesis-block proliferation index (CBPI). Since micronucleus expression is dependent on cell proliferation, quantification of cell proliferation and cell death should be carried out to obtain a sound evaluation of cell kinetics and micronucleus frequencies.

The CBPI was calculated as suggested by Surralle et al, ${ }^{17}$ that is

$$
\mathrm{CBPI}=\frac{\text { No. mononucleated cells }+2 \times \text { No. binucleated cells }+3 \times \text { No. multinucleated cells }}{\text { Total number of cells }}
$$

For the analysis of MN, only BN cells with well-preserved cytoplasm were scored for $\mathrm{MN}$ (under a light microscope with a 40 $\times 10$ magnification). The criteria for the selection of $\mathrm{BN}$ cells and identification of $\mathrm{MN}$ given in the HUMAN project website (http://www.humn.org) were followed.

The numbers of $\mathrm{BN}$ cells with 1, 2, 3, or more $\mathrm{MN}$ were then tabulated. The data for each treatment were expressed as the frequency of $\mathrm{MN}$ per $1000 \mathrm{BN}$ cells.

\section{Statistical Analysis}

The statistical analysis was performed using Origin software package version 7.0. The statistical significance of the difference between the data pairs was evaluated by analysis of variance (ANOVA; one-way ANOVA), followed by the Tukey test.
Statistical difference was considered significant at $P<.01$. The index calculated is presented as the $\%$ of change comparing different groups.

\section{Acknowledgments}

The authors would like to thank the Ministry of Education, Science and Technological Development of the Republic of Serbia (contract numbers: 451-03-9/2021-14/200026, 451-03-9/2021-14/200168) and the Serbian Academy of Sciences and Arts (Grant No. F188).

\section{Ethical Approval}

The study complied with the code of ethics of the World Medical Association (Helsinki Declaration of 1964, as revised in 2002). The blood samples were obtained at the Medical Unit in accordance with 
the current health and ethical regulations in Serbia (Parliament of the Republic of Serbia. Law on Health Care. Official Gazette of the Republic of Serbia 2005; 107: 112-161)

\section{ORCID iD}

Miroslav Novakovic (iD https://orcid.org/0000-0002-4984-041X

\section{Statement of Human and Animal Rights}

All procedures in this study were conducted in accordance with the Law on Health Care, Parliament of the Republic of Serbia Official Gazette of the Republic of Serbia 2005; 107: 112-161.

\section{Statement of Informed Consent}

Verbal informed consent was obtained from the patient(s) for their anonymized information to be published in this article.

\section{Declaration of Conflicting Interests}

The authors declared no potential conflicts of interest with respect to the research, authorship, and/or publication of this article.

\section{Funding}

The authors disclosed receipt of the following financial support for the research, authorship, and/or publication of this article: This work was supported by the Ministry of Education, Science and Technological Development of the Republic of Serbia (contract numbers: 451-03-9/2021-14/200026 and 451-03-9/2021-14/200168) and the Serbian Academy of Sciences and Arts (Grant No. F188).

\section{References}

1. http://www.theplantlist.com/1.1/browse/A/Anacardiaceae/ Cotinus/

2. Matić S, Stanić S, Mihailović M, Bogojević D. Cotinus coggygria scop: an overview of its chemical constituents, pharmacological and toxicological potential. Saudi J Biol Sci. 2016;23(4):452-461. https:// doi.org/10.1016/j.sjbs.2015.05.012

3. Gospodinova Z, Bózsity N, Nikolova M, Krasteva M, Zupkó I. Antiproliferative properties against human breast, cervical and ovarian cancer cell lines, and antioxidant capacity of leaf aqueous ethanolic extract from Cotinus coggygria scop. Acta Med Bull. 2017;44(2):20-25. https://doi.org/10.1515/amb-2017-0014

4. Novaković M, Vučković I, Janaćković P, Soković M, Filipović A, Tešević V, Milosavljević S. Chemical composition, antibacterial and antifungal activity of the essential oils of Cotinus coggygria from Serbia. J Serb Chem Soc. 2007;72(11):1045-1051. https://doi.org/ 10.2298/JSC0711045N

5. Du H, Liu G, Zhang Z, Cong Y. Isolation and identification of fisetin in Cotinus coggygria. Zhongyao Tongbao. 1983;8(1):29-30.

6. Westenburg HE, Lee KJ, Lee SK, Fong HHS, van Breemen RB, Pezzuto JM, Kinghorn AD. Activity-guided isolation of antioxidative constituents of Cotinus coggygria. J Nat Prod. 2000; 63(12):1696-1698. https://doi.org/10.1021/np000292h

7. Valinaou L, Stathopoulou K, Karapanagiotis I, Magiatis P, Pavlidou E, Skaltsounis A-L, Chryssoulakis Y. Phytochemical analyses of young fustic (Cotinus coggygria heartwood) and identification of isolated colourants in historical textiles. Anal Bioanal Chem. 2009;394:871-882. https://doi.org/10.1007/s00216-009$2767-z$

8. Antal DS, Schwaiger S, Ellmerer-Muller EP, Stuppner H. Cotinus coggygria wood: novel flavanone dimer and development of an HPLC/UV/MS method for the simultaneous determination of fourteen phenolic constituents. Planta Med. 2010;76(15):17651772. https.//doi.org/10.1055/s-0030-1249878

9. Novakovic M, Djordjevic I, Todorovic N, Trifunovic S, Andjelkovic B, Mandic B, Jadranin M, Vuckovic I, Vajs V, Milosavljevic S, Tesevic V. New aurone epoxide and auronolignan from the heartwood of Cotinus coggygria scop. Nat Prod Res. 2019;33(19):2837-2844. https://doi.org/10.1080/14786419. 2018.1508141

10. Vučković I, Vajs V, Stanković M, Tešević V, Milosavljević S. A new prenylated flavanonol from Seseli annuum roots showing protective effect on human lymphocytes DNA. Chem Biodiver. 2010;7(3):698-704. https://doi.org/10.1002/cbdv.200900067

11. Novaković M, Stanković M, Vučković I, Todorović N, Trifunović S, Apostolović D, Mandić B, Veljić M, Marin P, Tešević V, Vajs V, Milosavljević S. Diarylheptanoids from green Alder bark and their potential for DNA protection. Chem Biodiver. 2014;11(6):872-885. https://doi.org/10.1002/cbdv.201300277

12. Krstić G, Jadranin M, Stanković M, Aljančić I, Vujisić Lj, Mandić B, Tešević V. Jatrophane diterpenoids with protective effect on human lymphocytes DNA. Nat Prod Commun. 2019;14(5):1-7. https://doi. org/10.1177/1934578X19848168

13. Godevac D, Tesevic V, Vajs V, Milosavljevic S, Stankovic M. Antioxidant evaluation of heterocyclic compounds by cytokinesisblock micronucleus assay. Mini-Rev Med Chem. 2013;13(3):431-438. https://doi.org/10.2174/138955713804999856

14. Countryman RI, Heddle JA. The production of micronuclei from chromosome aberrations in irradiated cultures of human lymphocytes. Mutat Res. 1976;41(2-3):321-332. https://doi.org/10.1016/ 0027-5107(76)90105-6

15. Fenech M. The cytokinesis-block micronucleus technique: a detailed description of the method and its application to genotoxicity studies in human populations. Mutat Res. 1993;285(1):35-44. https://doi.org/10.1016/0027-5107(93)90049-L

16. Fenech M. A mathematical model of the in vitro micronucleus assay predicts false negative results if micronuclei are not specifically scored in binucleated cells or in cells that have completed one nuclear division. Mutagenesis. 2000;15(4):329-336. https://doi. org/10.1093/mutage/15.4.329

17. Surralle's J, Xamena N, et al. Induction of micronuclei by five pyrethroid insecticides in whole-blood and isolated human lymphocyte cultures. Mutat Res. 1995;341(3):169-184. https://doi. org/10.1016/0165-1218(95)90007-1

18. OECD. Guideline for the testing of chemicals: In Vitro Mammalian Cell Micronucleus Test, Test No. 487; OECD, 2016.

19. Amić D, Davidović-Amić $\mathrm{D}$, Bešlo $\mathrm{D}$, Trinajstić $\mathrm{N}$. Structure-radical scavenging activity relationships of flavonoids. Croat Chem Acta. 2003;76(1):55-61. 
20. Kaur P, Purewal SS, Sandhu KS, Kaur M. DNA Damage protection: an excellent application of bioactive compounds. Bioresour Bioprocess. 2019;6(2):1-11. https://doi.org/10.1186/s40643-0190237-9

21. Evans MD, Dizdaroglu M, Coke MS. Oxidative DNA damage and disease: induction, repair and significance. Mutat Res Rev Mutat Res. 2004;567(1):1-61. https://doi.org/10.1016/j.mrrev. 2003.11.001

22. Coppede F, Migliore L. DNA damage and repair in Alzheimer's disease. Curr Alzheimer Res. 2009;6(1):36-47.

23. Nakabeppu Y, Tsuchimoto D, Yamaguchi H, Sakumi K. Oxidative damage in nucleic acids and Parkinson's Disease. J Neurosci Res. 2007;85(5):919-934. https://doi.org/10.1002/jnr. 21191

24. Sanders LH, Greenamyre TJ. Oxidative damage to macromolecules in human Parkinson disease and the rotenone model. Free Rad Biol Med. 2013;62:111-120. https://doi.org/10.1016/j. freeradbiomed.2013.01.003

25. Islam A, Islam MS, Rahman MK, Uddin MN, Akanda MR. The pharmacological and biological roles of eriodictyol. Arch Pharm Res. 2020;43:582-592. https://doi.org/10.1007/s12272-02001243-0

26. Topal F, Nar M, Gocer H, Kalin P, Kocyigit UM, Gulcin I, Alwasel SH. Antioxidant activity of taxifolin: an activity-structure relationship. J Ensyme Inbib Med Chem. 2016;31(4):674-683. https://doi. org/10.3109/14756366.2015.1057723

27. Areiasa FM, Rego AC, Oliveira CR, Seabra RM. Antioxidant effect of flavonoids after ascorbate $/ \mathrm{Fe}^{2+}$-induced oxidative stress in cultured retinal cells. Biochem Pharmacol. 2001;62(1):111-118. https:// doi.org/10.1016/S0006-2952(01)00621-9

28. Sunil C, Xu B. An insight into the health-promoting effects of taxifolin (dihydroquercetin). Phytochemistry. 2019;166:112066. https:// doi.org/10.1016/j.phytochem.2019.112066

29. Zhang R, Kang KA, Piao MJ, Chang WJ, Maeng YH, Chae S, Lee IK, Kim BJ, Hyun JW. Butin reduces oxidative stress-induced mitochondrial dysfunction via scavenging of reactive oxygen species. Food Chem Toxicol. 2010;48(3):922-927. https://doi.org/ 10.1016/j.fct.2010.01.001

30. Zhang R, Lee IK, Pia MJ, Kim KC, Kim AD, Kim SH, Chae S, Kim SH, Hyun JW. Butin $\left(7,3^{\prime}, 4^{\prime}\right.$-trihydroxydihydroflavone) reduces oxidative stress-induced cell death via inhibition of the mitochondria-dependent apoptotic pathway. Int J Mol Sci. 2011;12(6):3871-3887. https://doi.org/10.3390/ijms12063871

31. Sadasivam K, Praveena R, Anbakzhakan K. Radical scavenging behavior of eriodictyol and fustin flavonoid compounds-a DFT study. AIP Conf Proc. 2018;1953(1):140001. https://doi. org $/ 10.1063 / 1.5033176$

32. Choi YJ, Do GM, Shin J-H, Kim JY, Kwon O. Standardized Rhus verniciflua Stokes extract and its major flavonoid fustin attenuate oxidative stress induced by tert-butyl hydroperoxide via activation of nuclear factor erythroid 2-related factor. J. Korean Soc Appl Biol Chem. 2014;57:27-30. https://dx.doi.org/10.1007/s13765-0134201-7

33. Park BC, Lee YS, Park H-J, et al. Protective effects of fustin, a flavonoid from Rhus verniciflua stokes on 6-hydroxydopamine- induced neuronal cell death. Exp Mol Med. 2007;39(3):316-326. https://doi.org/10.1038/emm.2007.35

34. Kim M-Y, Chung I-M, Choi D-C, Park H-J. Quantitative analysis of fustin and sulfuretin in the inner and outer heartwoods and stem bark of Rhus verniciflua. Nat Prod Sci. 2009;15(4):208-212.

35. Semwal RB, Semwal DK, Combrinck S, Viljoen A. Butein: from ancient traditional remedy to modern nutraceutical. Phytochem Lett. 2015;11:188-201. https://dx.doi.org/10.1016/j.phytol.2014. 12.014

36. Samoszuk M, Tan J, Chorn G. The chalcone butein from Rhus verniciflua Stokes inhibits clonogenic growth of human breast cancer cells co-cultured with fibroblasts. BMC Complement Alter Med. 2005;5:1-5. https://doi.org/10.1186/1472-6882-5-5

37. Jayasooriya RGPT, Molagoda IMN, Park C, Jeong J-W, Choi YH, Moon D-O, Kim M-O, Kim G-Y. Molecular chemotherapeutic potential of butein: a concise review. Food Chem Toxicol. 2018;112:1-10. https://doi.org/10.1016/j.fct.2017.12.028

38. Padmavathi G, Roy NK, Bordoloi D, Arfuso F, Mishra S, Sethi G, Bishayee A, Kunnunmakkara AB. Butein in health and disease: a comprehensive review. Phytomedicine. 2017;25:118-127. https:// doi.org/10.1016/j.phymed.2016.12.002

39. Grochová $\mathrm{D}$, Šmardová J. The antimutagenic and cytoprotective effects of amifostine: the role of p53. J Appl Biomed. 2007;5:171178. https://doi.org/10.32725/jab.2007.023

40. Badhani B, Sharma N, Kakkar R. Gallic acid: a versatile antioxidant with promising therapeutic and industrial applications. RSC Adv. 2015;5:27540-27557. https://doi.org/10.1039/C5RA01911G

41. Detsi A, Majdalani M, Christos K, Hadjipavlou-Litina DJ. Natural and synthetic 2 '-hydroxy-chalcones and aurones: synthesis, characterization and evaluation of the antioxidant and soybean lipoxygenase inhibitory activity. Bioorg Med Chem. 2009;17(23):8073-8085. https://dx.doi.org/10.1016/j.bmc.2009.10.002

42. Lee JC, Lee KY, Kim J, Na C-S, Jung N-C, Chung G-H, Jang Y-S. Extract from Rhus verniciflua Stokes is capable of inhibiting the growth of human lymphoma cells. Food Chem Toxicol. 2004;42:1383-1388. https://doi.org/10.1016/j.fct.2004.03.012

43. Kumar Vermaa A, Pratap R. The biological potential of flavones. Nat Prod Rep. 2010;27(11):1571-1593. https://doi.org/10.1039/ C004698C

44. Cheng Z-J, Kuo S-C, Chan S-C, Ko F-N, Teng C-M. Antioxidant properties of butein isolated from Dalbergia odorifera. Biochim Biophys Acta. 1998;1392(2-3):291-299. https://doi.org/10.1016/s00052760(98)00043-5

45. Lee J-C, Lim K-T, Jang Y-S. Identification of Rhus verniciflua Stokes compounds that exhibit free radical scavenging and anti-apoptotic properties. Biochim Biophys Acta. 2002;1570:181-191. https://doi. org/10.1016/s0304-4165(02)00196-4

46. Trouillas P, Marsal P, Svobodova A, Vostalova J, Gažak R, Hrbač J, Sedmera P, Kren V, Lazzaroni R, Duroux J-L, Walterova D. Mechanism of the antioxidant action of silybin and 2,3-dehydrosilybin flavonolignans: a joint experimental and theoretical study. J Phys Chem A. 2008;112(5):1054-1063. https://doi. org/10.1021/jp075814h 